\title{
AN ANNULLED AWARD CANNOT BE ENFORCED UNDER THE NEW YORK CONVENTION $\Omega$
}

\author{
Faizal Kurniawan \\ Faculty of Law Universitas Airlangga, Indonesia \\ E-mail: faizal@fh.unair.ac.id
}

\begin{abstract}
Arbitral award is final and binding. A concept of "binding" is fundamental in International arbitral award. Nevertheless, the focus commonly concerns about the annulment and/or deferment of International arbitral award so that it could not be implemented. However, the New York Convention does not govern this issue. In addition, international arbitral awards must meet the following requirements: the award is made in the territory other than conflicting countries, and/ or it is not considered a domestic awards in the State where recognition and enforcement is sought. This is important because the enforcement proceedings between foreign and domestic awards are different. This article elaborates the principles of the recognition and enforcement of a foreign award and the grounds or criteria for refusing to enforce an award are limited to the specific defenses i.e. public policy. The party opposing enforcement bears the burden of proof in the existence of the enumerated defenses.
\end{abstract}

Keywords: binding, annullment, deferment, acknowledgement and enforcement of arbitral award.

\begin{abstract}
Abstrak
Putusan Arbitrase tentunya bersifat final dan mengikat. Konsep "mengikat"-nya suatu putusan arbitrase merupakan suatu hal yang mendasar apabila berbicara mengenai putusan arbitrase Internasional. Akan tetapi, hal yang paling sering menjadi fokus perhatian adalah mengenai pembatalan dan/ atau penundaan putusan arbitrase Internasional dengan tujuan agar putusan tersebut tidak dapat dilaksanakan. Sedangkan, New York Convention sendiri tidak mengatur mengenai pembatalan putusan arbitrase Internasional. Sebagai tambahan, putusan arbitrase Internasional harus memenuhi syaratsyarat sebagai berikut: putusan tersebut dijatuhkan di negara di luar negara pihak yang bersengketa dan tidak dikualifikasikan sebagai putusan arbitrase nasional. Hal ini penting mengingat karakter antara putusan arbitrase internasional dan nasional jelas berbeda. Artikel ini mengelaborasi mengenai prinsip-prinsip pengakuan dan pelaksanaan putusan arbitrase internasional dan dasar atau kriteria untuk membatalkan putusan arbitrase internasional dengan alasan, misalnya melanggar ketertiban umum. Pihak yang mengajukan alasan pembatalan putusan arbitrase internasional menanggung beban pembuktian dengan mengemukakan alasan-alasan yang dianggap sah untuk itu.
\end{abstract}

Kata kunci: mengikat, pembatalan, penundaan, pengakuan dan pelaksanaan arbitrase internasional

\section{Introduction}

Established in 1958, the New York Convention came into effect in June 1959. It was viewed as the foundation instrument of international arbitration and required courts of contracting States to give effect to an agreement to arbitrate. One of the figures involved in the establishment of the Convention was Pieter Sanders. In 1999 at the $40^{\text {th }}$ anniversary celebration of the Convention, he shared it in his lectures at The Hague. He compared international arbitration to a bird saying, "It rises in the air, but from time to time it falls back on its nest. In my [Mr. Sanders'] opinion this still applies today". ${ }^{1}$

$\Omega \quad$ The author wishes to express his most sincere gratitude to Kunti Kalmasyita, S.H., M.H. and Frita Sofia, S.H. to their excellent research of legal cases to support this article.

1 Pieter Sanders, "The Making of the Convention", speech, the papers presented at "New York Convention Day". That colloquium was held in the Trusteeship Council Chamber of the United Nations Headquarters, New York on 10 June 1998 to celebrate the $40^{\text {th }}$ anniversary of the Convention on the Recognition and Enforcement of Foreign Arbitral Awards concluded on 10 June 1958, New York, 1999, page 4, available from https://www. 
Despite considerable progress made by the Convention in harmonizing the enforcement of foreign awards, the enforcement process is sometimes considered the weakest link in the entire chain of international dispute resolution. ${ }^{2}$ Indeed, the enforcement proceedings are still dependent on national laws/ rules, which differ in many aspects in different parts of the world. On the other hand, in the US, it will strictly limit to suspend or annul the foreign award by the doctrine of resjudicata. ${ }^{3}$ Thus in this respect, the New York Convention does not deal with the annulment of award(s), instead, it deals only with the recognition and enforcement of foreign arbitral award.

In an attempt to answer the major question, apart from the introduction given above, the paper discusses the following subjects: first, Recognition and Enforcement of Arbitral Awards; and second, The criterion of awards which is not legally binding, annulled or suspended.

In addition, interrelation to the Geneva Convention 1961 will be described and the future approach of The New York Convention. Furthermore, we will discuss different point of views with regards to the location of annullment and the forum of enforcement, Country obligation and finally, our conclusion.

\section{Discussion \\ Recognition and Enforcement of Arbitral Awards}

Broadly speaking, a foreign arbitral should meet some requirements to distinguish it from national arbitral award. It is rendered abroad in which one party is foreign citizen or in which the object is over foreign property. Awards rendered to settle disputes between parties of different countries need international recognition

uncitral.org/pdf/english/texts/arbitration/NY-conv/NYC Day-e.pdf, accessed in June $11^{\text {th }} 2010$.

2 Marc Blessing, "The New York Convention: The Major Problem Areas, in: The New York Convention of 1958", ASA Special Series No. 9, 1996, Zurich: Swiss Arbitration Association, page 20.

3 Michael A. Rosenhouse, "Confirmation of Foreign Arbitral Award under Convention on Recognition and Enforcement of Foreign Arbitral Awards", American Law Reports, 194 A.L.R. Fed. 291, 2004, New York: Thomson Reuters, page 295. and enforcement procedures. Multilateral conventions such as the New York Convention, and bilateral treaties such as the Treaty of Friendship, Commerce and Navigation between two countries, were signed and ratified to enable inter-jurisdictional awards to be made and enforced. According to Article 1(1) of the New York Convention, an arbitral award qualifies as foreign in two situations: first, when the award is made in the territory of another State; or second, when it is not considered a domestic award in the State where recognition and enforcement is sought.

The question whether an award is domestic or foreign is of particular important because in any jurisdictions the enforcement proceedings for foreign and domestic awards are different. Due to the diversity of the approaches of national legal systems to the enforcement of arbitral awards, including the grounds for nonenforceability, it has occurred that enforcement has been refused in one State but granted in another.

States that, those who are signatory to the New York Convention agree to abide by findings and judgments made within its confines. Currently, 144 of the United Nations' out of 192 member states agree to accept the Convention; of course enforceability is an issue only between and among those 144 states agreeing to be bound by the Convention. Among those 144 states, there are issues and conditions under which arbitration decisions can be set aside.

It is clear that the application of the New York Convention is only about the recognition and enforcement of foreign and non-domestic arbitral awards. A-contario, it can be said that the New York Convention does not apply to the recognition and enforcement of domestic award. It is important to identify whether the award is classified to a foreign and/ or a nondomestic award. Article I (1) of the New York Convention stipulates:

"This Convention shall apply to the recognition and enforcement of arbitral awards made in the territory of a State other than the State where the recognition and enforcement of such awards are sought, 
and arising out of differences between persons, whether physical or legal. It shall also apply to arbitral awards not considered as domestic awards in the State where their recognition and enforcement are sought."

Accordingly, there are two categories to limit the application of the New York Convention. First, the article emphasizes that the award is classified as a foreign award when it is made in a state other than the state of recognition or enforcement of such awards are sought. However, the New York Convention does not stipulate explicitly the classification of a foreign award. The seat of arbitration may be one of considerations in determining a foreign award. It has to be identified if the rendering court has the competent authority which belongs by two category i.e. lex loci arbitri and the contractual arrangement made by the parties. ${ }^{4}$

Secondly, there is a concept of non-domestic award that may restrict the application of this Convention. Again, the New York Convention does not clearly define non-domestic awards. The criteria for an award to be measured as non-domestic awards, as follows: Awards rendered under the arbitration law of another state, Awards connecting a foreign element, and a national award which is not ruled by any arbitration law. Basically, with regard to this convention, the non-domestic award may not only be interpreted that an award made in another contracting state but also the convention broadens its concept into those criteria. Albert added that, for example, parties may agree to arbitrate in France on the basis of West German arbitration law. The Convention refers to arbitral awards which are not only made in another country but also under the law of another country. ${ }^{5}$ Related to the first criterion, it is possible (especially for Civil Law countries) to agree to settle the parties' dispute before arbi-

Sujayadi, "Interaction between the Setting Aside of an Award and Leave for Enforcement", Yuridika, Vol. 30 No. 2, Mei-Agustus 2015, Surabaya: Airlangga University Press, pages 256-257.

5 Albert Van den Berg I, "When Is an Arbitral Award Non Domestic under New York Convention of 1958?", Pace Law Review, Vol. 6 Issue I, Fall September 1985, Rev. 25, New York: Pace Law School, pages 5-7. tration under the arbitration law of another country. The second criterion derives from the primary case in Bergesen v. Mubller that underlines foreign elements to define non-domestic awards i.e. which domicile of its business is outside the award rendered. The last criterion stresses that the applicable law is not the law of the country which the parties have excluded the application of any national arbitration law. It originates from the implementing legislation in the United States as interpreted by the courts in that country. The leading case is a 1983 decision by the US Court of Appeals for the Second Circuit in Bergesen v. Muiller. In Bergesen, the Court enforced an award made in New York under New York law between a Norwegian and a Swiss party by relying on the second definition contained in Article I(1). The Court adopted the view that "awards 'not considered as domestic' means awards which are subject to the Convention not because of being made abroad, but made within the legal framework of another country, e.g., pronounced in accordance with a foreign law or involving parties domiciled or having their principal place of business outside the enforcing jurisdiction".

As regards category (iii), it is argued that the second definition supports the Convention's applicability to the recognition and enforcement of arbitral awards that do not result from the ambit of the applicability of any national arbitration law. In case of enforcement of an "anational" award under the Convention, the place where the award was made is in principle irrelevant. It is controversial whether "de-nationalized" arbitration and the resulting "a-national" award are legal reality and if so, whether the New York Convention can be applied to them. Therefore, these mentioned criteria become the basic consideration to the parties seeking the recognition and enforcement of an award.

Basically, the New York Convention provides for the grounds under which the recognition and enforcement of an arbitral award may 
be refused to be enforced. ${ }^{6}$ It is stated that Article III of the New York Convention subjects enforcement actions to procedural requirements of the signatory States. It provides that each Contracting State "shall recognize arbitral awards as binding and enforce them in accordance with the rules of procedure of the territory where the award is relied upon...". In other words, each signatory State in principle applies its own procedural rules in taking the actions required by the Convention, that is, in actually recognizing or enforcing (or refusing to recognize or enforce) foreign arbitral awards. The grounds prescribed in Article $\mathrm{V}$ may be divided into two categories: (i) those that may be invoked by the parties (Article V (1) (a)-(d)) of the Convention especially which are to be proven by the respondent, and (ii) those that the court may be invoked by the court on its motion (Article V (2)).

Whereas the first category is intended to protect the interests of the award-debtor, the second serves the vital interests of the forum country. There are others, but it is the enforceability of an annulled arbitration agreement that is of interest here.

Criterion of Awards which is not Legally Binding, Set Aside or Suspended

As far as the question of setting aside award at the seat is concerned, the New York Convention, 1958 sets forth no grounds. On the other hand, we can compare it to the UNCITRAL Model Law, under Article 34(2), allows setting aside on such grounds as nullity of arbitration agreement, procedural deficiencies, and public policy. ${ }^{7}$ Model Law does not allow the review of the merits but the laws of some countries do.

6 George A. Bermann, "Recognition and Enforcement of Foreign Arbitral Awards: The Application of the New York Convention by National Courts", (unpublished manuscript) (on file with the New York University Law Review), page 76 , available at http://www.iacl2014 congress.com/fileadmin/user_upload/k_iacl2014congres s/General_reports/Bermann_-_General_Report_Recogni tion_Enforcement_of_Foreign_Awards_July_2_2014_2 .pdf, accessed on 18 February 2017.

7 Peter Binder, 2010, International Commercial Arbitration and Conciliation in UNCITRAL Model Law Jurisdictions, $3^{\text {rd }}$ edition, England: Sweet \& Maxwell, pages 423 424.
On this ground, enforcement can be refused if the respondent asserts and proves that the award has not yet become binding on the parties, or has been set aside or suspended by a competent authority of the country in which, or under the law of which, that award was made. Reference is made here to three separate grounds, each of which will be considered in turn. The reason is to respond that the award has no legally binding if it does not comply with the law where the award was made. It is necessary to hinder "double exequatur" in both the rendering and enforcing state. ${ }^{8}$

\section{Binding}

Ground (e) of Article V (1) provides first that enforcement of an award can be refused if the party against whom the award is invoked proves that the award has not become 'binding'. Back to the 1927 Geneva Convention, the same required the award to have become 'final' in the country of origin. The word 'final' was interpreted by many courts at the time as requiring leave for enforcement (exequatur or the like) to have been granted by a court in the country of origin. ${ }^{9}$

Since the country where enforcement was sought also required leave for enforcement, this interpretation led in practice to what was called a 'double exequatur'. The drafters of the New York Convention considered this system to be too cumbersome and abolished it by using the word 'binding' instead of 'final'. Accordingly, no leave for enforcement in the country of origin is required under the New York Convention. Courts are virtually unanimous in their acceptance of this principle. ${ }^{10}$

Courts differ, however, over the question of whether the binding force is to be determined under the law applicable to the award or

8 Ramona Martinez, "Recognition and Enforcement of International Arbitral Awards Under the United Nations Convention of 1958: The "Refusal" Provisions", American Bar Association, 24(2), Summer 1990, 24 Int'l Law. 48724 Int'l Law. 487, New York: the International Lawyer, page 487.

9 Albert Jan Van Den Berg, 2003, Yearbook Commercial Arbitration 2003-Volume. XXVIII, The Hague, Netherlands: Kluwer Law International, page 17.

10 Ibid. 
independently of the applicable law. While some courts look at the applicable law to find out whether the award has become binding under that law, other courts interpret the word 'binding' without regard to an applicable law, as meaning that the award can no longer be appealed on the merits in further proceedings before another arbitral tribunal or in a court. As comparison, the questions will also rise related to the award made by sharia-based arbitration in achieving the dispute of Islamic commercial law. ${ }^{11}$ Would the principle of the New York Convention prevail vis-à-vis to the Sharia-based arbitration? Indonesia recognizes the national Sharia Board of Arbitration (Basyarnas) to handle the Islamic economic settlements. This poses a problem that which court has authority to examine the sharia-foreign award. ${ }^{12}$

\section{Set Aside}

Ground (e) further provides that enforcement of an award can be refused if the party against whom the award is invoked proves that the award has been 'set aside' (annulled or vacated) by a court in the country where, or under the law of which, the award was made. ${ }^{13}$

According to Article VI of the Convention, a court may adjourn its decision on enforcement if the respondent has applied for the award to be set aside in the country of origin. In a number of reported cases, the setting aside of an award in the country where it was made had caused enforcement abroad to be refused under the Convention. For instance, in one case decided in 2007, it was decided that an injunction could be appealed and even overturned because of the facts of the specific case, Karaha Bodas Co., L.L.C. v. Perusahaan Pertambangan Minyak Dan Gas Bumi Negara (Docket No. 07-0065-cv, United States Court of Appeals, Second Circuit,

11 Almas Khan, "The Interaction between Shariah and International Law in Arbitration", Chicago Journal of International Law, Vol. 6 No. 2, Article 16, Chicago: The University of Chicago, pages 794-796.

12 Rahadi Wasi Bintoro, "Restrictions on the Religious Judiciarys' Authority as a Result of judicial power conflict rules", Jurnal Dinamika Hukum, Vol. 15 No. 2, May 2015, Purwokerto: Faculty of Law Universitas Jenderal Soedirman, pages 211-212.

13 Albert Jan Van Den Berg I, Loc.Cit.
September 7, 2007). In explaining the decision, the Court stated, it would be inconsistent with our obligations under the Convention to bar good-faith litigation over the Award in Switzerland, the jurisdiction with primary authority over the Award. The arbitration results achieved at an earlier time gained an injunction against one of the parties preventing seeking enforcement, but the Court of Appeals altered that injunction slightly so that one of the parties could seek additional legal action and decision in Switzerland, the state with ultimate jurisdiction in the dispute. ${ }^{14}$

Thus, in another cases the Court of Appeals for the Second Circuit refused the enforcement of two awards set aside by a court in Nigeria (Baker Marine - US Court of Appeals, Second Circuit, 12 August 1999, Baker Marine (Nig.) Ltd. v. Chevron (Nig.) Ltd. et al.); the Court of Appeals for the District of Columbia refused the enforcement of an award set aside by a court in Colombia (TermoRio-US Court of Appeals for the District of Columbia, TermoRio S.A. E.S.P. et al. v. Electranta S.P., et al., 25 May 2007, No. 06-7-58); the District Court for the Southern District in New York refused enforcement of an award set aside by a court in Italy (Spier - US District Court, Southern District of New York, 22 October and 29 November 1999, Martin I. Spier v. Calzaturificio Tecnica S.p.A); and the Court of Appeal in Rostock refused the enforcement of an award set aside by a Russian court (Oberlandesgericht [Court of Appeal], Rostock, 28 October 1999).

\section{Suspended}

Again, the enforcement of an award can be refused if the party against whom the award is invoked proves that the award has been 'suspended' by a court in the country where, or under the law of which, the award was made.

The foregoing raises problems with awards made in Paris against which an action for setting aside was brought in the French courts. Under French (international) arbitration

\footnotetext{
14 Christopher Koch, "The Enforcement of Awards Annuled in Their Place of Origin: The French and U.S. Experience", Journal of International Arbitration, Vol. 26 No. 2, 2009, Kluwer Law International: The Netherlands, page 267.
} 
law (namely Article 1502 of the French Code of Civil Procedure), such action suspends the enforcement of the award by operation of law. Two foreign courts have nonetheless held that such suspension is sufficient to meet the requirement of ground (e) of Article V (1)(e) of the Convention.

For instance, the United States law 9 U.S.C. Sect. 201, provides for the enforcement of arbitration agreements that have been established using the New York Convention. ${ }^{15}$ Articles II and III of the Convention are supported by the US law, which reads, the court shall confirm the award unless it finds one of the grounds for refusal or deferral of recognition or enforcement of the award specified in the Convention ${ }^{16}$. The decision in United States District Court, Northern District of Illinois, Eastern Division, 12 April 2005, No. 04 C 7731 referenced the case of Karaha Bodas Co., L.L.C. v. Perusahaan Pertambangan Minyak Dan Gas Bumi Negara, which at the time was being appealed.

Again, in one case, the Court of First Instance in Geneva refused enforcement of an award made in France because the respondent had filed an application to set aside the award in a French court (Tribunal de Première Instance [Court of First Instance], Geneva, 25 April 1985, and Cour de Justice [Court of Appeal], Geneva, 10 October 1985, Continaf BV v. Polycoton SA). However, it should be noted that the common point of these cases is that; "The grounds for refusing to enforce an award are limited to the specific defenses enumerated in Art. $\mathrm{V}$ of the New York Convention. The party opposing enforcement bears the burden of proving the existence of the enumerated defenses" (United States District Court, Northern District of Illinois, Eastern Division, 12 April 2005, No. 04 ( 7731).

On the other hand, the combined effect of Article VII and local laws suggests that no award can be enforced as such an award will be annulled $a b$ initio. However, a word on the

\footnotetext{
15 Albert Jan Van Den Berg III, 2006, Yearbook Commercial Arbitration 2006-Volume XXXI, The Hague, Netherlands: Kluwer Law International, page 1154.

16 Ibid.
}

func-tions of Article V(1)(e) appears strange to the NYC. Whereas sub paragraphs (a)-(d) lays down grounds for the refusal of enforcement which is intrinsic to the award or proceedings, subparagraph (e) refers to extrinsic factors (annulment by the Court) In our opinions, such annulment may have been premised on reasons laid down in subparagraphs (a)-(d). Therefore, in technical terms Article $\mathrm{V}(1)(\mathrm{e})$ is a lex specialis on res-judicata as it specifies the followings: First, the court of the country under which arbitration took place are international competent; Second, annulment proceedings are the results of annulled decision; and Third, if the enforcement forum applies Art. V(1)(e), the special collateral effect is to refuse enforcement of the award. ${ }^{17}$

For instance in the case of Putrabali $v$. Est Epices, ${ }^{18}$ an arbitral award issued in London had been set aside by the High Court of England and Wales in the same capital city. Enforcement was sought in France. The Cour de cassation granted enforcement of the first award "an international award, which does not form part of any national legal order, is an international decision of justice, and its validity should be examined under the rules applicable in the country where its recognition and execution are requested". As aforesaid, the second section of Article $\mathrm{V}$ of the Convention, provides that $\mathrm{a}$ court may refuse enforcement on its own motion if it finds that the subject matter of the difference is not capable of settlement by arbitration under the law of the country where enforcement is sought or enforcement would be contrary to the public policy of that country. The cases in which these provisions have been relied upon for refusing enforcement involves the distinction drawn between domestic and international public policy, for what is considered public policy in domestic relations does not necessarily constitute public policy in international relations. For instance, the Supreme Court in case Oberster Gerichtshof [Supreme Court], 11

17 G.C. Petrochilos, "Enforcing Awards Annulled in their State of Origin under the New York Convention', International and Comparative Law Quarterly, Vol. 48 No. 4, 1999, New York: Cambridge University Press, page 876.

18 Christopher Koch, op.cit., page 268. 
May 1983, Dutch Appellant v. Austrian Appellee held that no distinction between domestic and international public policy was envisaged in Article V (2) (b) of the New York Convention as Article V (2) (b) of the Convention refers clearly to cases where an award is contrary to the public policy of the country where it shall be enforced. Other reasons are arbitrability, lack of impartiality, lack of implementing legislation, Jurisdiction over applications for enforcement (forum non Conveniens) and retroactive application of the Convention.

Interrelation to the Geneva Convention, 1961 Article IX provides that:

(1) "The setting aside in a Contracting State of an arbitral award covered by this Convention shall only constitute a ground for the refusal of recognition or enforcement in another Contracting State where such setting aside took place in a State in which, or under the law of which, the award has been made and for one of the following reasons:

- [a list replicating Article 34(2) of the Model Law save grounds of non-arbitrability and public policy]

(2) In relations between Contracting States that are also parties to the New York Convention ..., paragraph 1 of this Article limits the application of Article V(1)(e) of the New York Convention solely to the cases of setting aside set out under paragraph 1 above.

Thus, from the statement of Article IX of the Geneva Convention, the 1961 Geneva Convention seems to solve the problem or contradicttions of the application of Article V(1)(e) and VII (1) of the New York Convention. A useful illustration of the application of Article IX of the Geneva Convention by the Courts is provided by the Authority Supreme Court's decision in Radenska's case. In this case, the Court of Appeal of Gaz had refused to enforce an award set aside by the Slovenian Courts on the grounds that it contravened Slovenian public policy.

In short, the Slovenian Court reversed the lower court's decision holding that, "the non- accordance of an arbitral award with the public policy of the State in which it has been set aside is not included in the list of Article IX of the European Convention. This means that an arbitral award which has been set aside in its origin for violation of public policy can be effective in the other Contracting State, the public policy of which it does not violate. Although the Geneva Convention is limited to scope of application, but it is counted as a supplement and complimentary to the New York Convention. These two Conventions may apply together.

Broadly speaking, the New York Convention was intended to make it easier to enforce an arbitral award rendered in one country in the courts of other countries. Because of this focus, the New York Convention assigns responsibilities to and certain obligations on the judge at the place of enforcement (discretionary power). As an international agreement, the Convention cannot dictate to sovereign nations that they will decide matters as determined by an external entity.

Though each country remains free to make whatever rules it wishes with respect to the grounds on which they might invalidate an award rendered in their territory, member countries also have agreed to operate under the rules of the Convention. However, this consideration can be problematic when striving to apply Convention Article V (l) (e). That section makes it possible for courts to refuse to recognize or enforce foreign awards if they have been set aside by the courts in the country where they were rendered.

\section{Proposal of New Draft of the New York Con- vention}

According to the new draft of the New York Convention contributed by Albert Jan Van Den Berg at AIJA Conference, Paris 2008, he said that:

"Under the new draft, the courts must refuse the enforcement of an award which has been annulled in its state of origin, provided that the annulment was made on the basis of one of the grounds listed in the Convention. This would standardize procedure, while allowing the enforcing 
court flexibility to reject an annulment made on spurious grounds."

In my view, we do agree with his argumentation on the basic of International legal order. As we concern with the spirit of New York Convention of uniformity, the enforcement forum should rely upon international standards of annulment in order to refuse or allow the foreign arbitral award. ${ }^{19}$ Article VII (1) containing the more favorable provision allows a party to seek enforcement, rely not on the Convention itself but rather on the local laws where enforcement is sought. Thus, if the Convention would not allow enforcement, a party may still be able to obtain leave for enforcement on the basis of a more favorable domestic law concerning enforcement of foreign arbitral awards. ${ }^{20}$ Indeed, to have internationally standard of future understanding, I strongly agree with the Hans Smit that an annulled award should not be enforced in other state only if the award which has been annulled get in favor of the party who has nationality or domicile in the state of annulment. ${ }^{21}$

It is also noteworthy that not many countries have a statutory regulation for the enforcement of foreign arbitral awards by virtue article VII (l) of the Convention. We consider this a lost opportunity since article VII (l) is clearly an open offer to Contracting States. One of the few countries which used the opportunity offered by article VII (l) of the Convention are the Netherlands and France. Obviously, France has equally used the opportunity under article VII (l) of the Convention, as otherwise we would not have been able to enjoy the case of PT Putrabali and Hilmarton. A country may have a legal regime concerning the enforcement of for-

19 S.I. Strong, "What Constitutes an "Agreement in Writing" in International Commercial Arbitration? Conflicts between the New York Convention and the Federal Arbitration Act”, 48 Stan. J. Int'l L. 47, Stanford Journal of International Law, winter 2012, Standford: Standford Law School, page 76.

20 Markus A Petsche, 2005, "The Growing Autonomy of International Commercial Arbitration", Munchen: Sellier European Law Publishers, pages 101-104.

21 Hans Smit, "Annulment of An Arbitral Award And Its Subsequent Enforcement: Two Recent Decisions", American Review of International Arbitration, 19 Am. Rev. Int'l Arb. 187, 2008, Virginia: Washingthon \& Lee Law School, page 190. eign awards outside the Convention that is developed by case law. This may lead to misunderstandings in relation to article VII (l) of the Convention, as has been seen in the United States.

The statutory provisions on the enforcement of foreign awards being divergent or nonexistent in many countries would be preferable if an internationally recommended text of statutory provisions for enforcement of foreign awards outside the Convention was available. As an international community, we have to respect the decision of the court of origin as a unified decision even if the court vacated or set aside the award; of course, within an exception that such foreign award infringes public policy of the country which the award is sought. To abide with the legal standards, the court of origin shall remit the proceedings to the seat of arbitration with regards to its competence in conjunction with the setting aside of an arbitral award.

\section{Conclusion}

To sum up, as a general rule, once an arbitral award has been set aside in its home country, an enforcement of the same can no longer be sought in another country (Article $\mathrm{V}(1)(\mathrm{e})$ of the New York Convention). There is, however, an exception to the effect that, when an arbitral award despite of its having been set aside in a seat of arbitration may still be enforced in another country. There are other exceptions by virtue of Article $\mathrm{V}$ and VII of the New York Convention of 1958, i.e. cases of Hilmaton and Chromalloy.

The Conditions provided by the New York Convention are governed in Articles IV to VI of the Convention. It is, however, incorrect to see the convention as a guarantee of enforcement. The Convention provides the framework for enforcement but leaves questions of detailed procedure to local laws in the place where enforcement is sought.

Nevertheless, it should be noted that $\mathrm{Na}$ tional law cannot stipulate conditions for the recognition and enforcement of foreign arbitral awards that are substantially more onerous than those applicable to the recognition and enforce- 
ment of domestic arbitral awards. With the question whether the enforcement aspect of annulled agreements should be pursued at all, this will largely depend on the circumstance of the case. Consequently, this can lead to dispute over dispute resolution. ${ }^{22}$

From the above discussion, it assumes that an enforcement of an annulled award normally will depend on the circumstances of the case and largely on the law applicable in a State in which the enforcement is sought. In our opinions, it would be wrong to judge that an annulled award cannot be enforced under the New York Convention, 1958. The secondary court should respect the decision of the court that annulled or set aside the award, except in those rare cases that judgment is "repugnant to fundamental notions of what is decent and just".

\section{Suggestion}

It should be noted that the spirit of the New York Convention to bring uniformity in seeking justice and consistenly applied in all other countries in which the recognition and enforcement is sought. Parties must be confident that the New York Convention guarantees and limits the ground for refusal or suspension for the foreign arbitral award. We can see it in the US that the court will consistenly only be refused if the foreign arbitral award was shown by significant corruption or fraud.

\section{References}

Bermann, George A. "Recognition and Enforcement of Foreign Arbitral Awards: The Application of the New York Convention by National Courts". (Unpublished manuscript) (On file with the New York University Law Review). Available at http:// www.iacl2014congress.com/fileadmin/us er_upload/k_iacl2014congress/General_r eports/Bermann_-_General_Report_Recog nition_Enforcement_of_Foreign_Awards_ July_2_2014_2_.pdf. Accessed on February $18^{\text {th }} 2017$.

Binder, Peter. 2010. International Commercial Arbitration and Conciliation in UNCITRAL

22 Marc J. Goldstein, "Setting Aside N.Y. Convention Awards Made in the U.S.", Dispute Resolution Journal, 64 no. 2, July 2009, New York: Juris Publishing, page 11.
Model Law Jurisdictions. $3^{\text {rd }}$ edition. England: Sweet \& Maxwell;

Bintoro, Rahadi Wasi. "Restrictions on the Religious Judiciarys' Authority as a Result of judicial power conflict rules". Jurnal Dinamika Hukum. Vol. 15 No. 2. May 2015. Purwokerto: Faculty of Law Universitas Jenderal Soedirman;

Blessing, Marc. "The New York Convention: The Major Problem Areas. in: The New York Convention of 1958”. ASA Special Series No. 9. 1996. Zurich: Swiss Arbitration Association;

Goldstein, Marc J. "Setting Aside N.Y. Convention Awards Made in the U.S.". Dispute Resolution Journal. 64 no. 2. July 2009. New York: Juris Publishing;

Jan van den Berg, Albert. "When Is an Arbitral Award Non Domestic under New York Convention of 1958?". Pace Law Review. Vol. 6 Issue I. Fall September 1985. Rev. 25. New York: Pace Law School;

Jan van den Berg, Albert. 2003. Yearbook Commercial Arbitration 2003 - Volume XXVIII. The Hague. Netherlands: Kluwer Law International;

Jan van den Berg, Albert. 2006. Yearbook Commercial Arbitration 2006 - Volume XXXI. The Hague. Netherlands: Kluwer Law International;

Khan, Almas. "The Interaction between Shariah and International Law in Arbitration". Chicago Journal of International Law. Vol. 6 No. 2. Article 16. Chicago: The University of Chicago;

Koch, Christopher. "The Enforcement of Awards Annuled in Their Place of Origin: The French and U.S. Experience". Journal of International Arbitration. Vol. 26 No. 2. 2009. Kluwer Law International: The Netherlands;

Martinez, Ramona. "Recognition and Enforcement of International Arbitral Awards Under the United Nations Convention of 1958: The "Refusal" Provisions". American Bar Association. Vol. 24 No. 2. Summer 1990. 24 Int'l Law. 48724 Int'l Law. 487. New York: the International Lawyer;

Petrochilos, G C. "Enforcing Awards Annulled in their State of Origin under the New York Convention'. International and Comparative Law Quarterly. Vol. 48 No. 4. 1999. New York: Cambridge University Press; 
Petsche, Markus A. 2005. "The Growing Autonomy of International Commercial Arbitration". Munchen: Sellier European Law Publishers;

Rosenhouse, Michael A. "Confirmation of Foreign Arbitral Award under Convention on Recognition and Enforcement of Foreign Arbitral Awards". American Law Reports. 194 A.L.R. Fed. 291. 2004. New York: Thomson Reuters;

Sanders, Pieter. "The Making of the Convention". Speech. The papers presented at "New York Convention Day". That colloquium was held in the Trusteeship Council Chamber of the United Nations Headquarters. New York on 10 June 1998 to celebrate the $40^{\text {th }}$ anniversary of the Convention on the Recognition and Enforcement of Foreign Arbitral Awards concluded on 10 June 1958. New York. 1999. available from https://www.uncitral.org/pdf/eng
lish/texts/arbitration/NY-conv/NYCDaye.pdf. Accessed on June $11^{\text {th }} 2010$.

Smit, Hans. "Annulment of an Arbitral Award and Its Subsequent Enforcement: Two Recent Decisions". American Review of International Arbitration. 19 Am. Rev. Int'l Arb. 187. 2008. Virginia: Washington \& Lee Law School;

Strong, S I. "What Constitutes an "Agreement in Writing" in International Commercial Arbitration? Conflicts between the New York Convention and the Federal Arbitration Act”. 48 Stan. J. Int'l L. 47. Stanford Journal of International Law. Winter 2012. Standford: Standford Law School;

Sujayadi. "Interaction between the Setting Aside of an Award and Leave for Enforcement". Yuridika. Vol. 30 No. 2. MeiAgustus 2015. Surabaya: Airlangga University Press. 